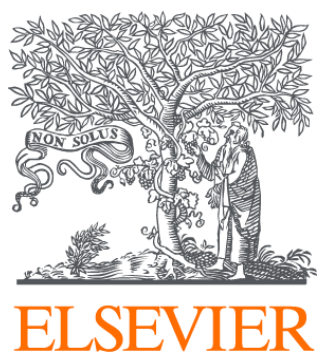

Since January 2020 Elsevier has created a COVID-19 resource centre with free information in English and Mandarin on the novel coronavirus COVID-

19. The COVID-19 resource centre is hosted on Elsevier Connect, the company's public news and information website.

Elsevier hereby grants permission to make all its COVID-19-related research that is available on the COVID-19 resource centre - including this research content - immediately available in PubMed Central and other publicly funded repositories, such as the WHO COVID database with rights for unrestricted research re-use and analyses in any form or by any means with acknowledgement of the original source. These permissions are granted for free by Elsevier for as long as the COVID-19 resource centre remains active. 


\title{
Viruses and diarrhoea
}

\author{
J. E. Banatvala \\ Department of Virology, St. Thomas' Hospital and Medical School, London SEI iEH
}

Acute gastro-enteritis is one of the leading causes of morbidity in infancy and childhood throughout the world and probably the leading cause of death in infancy in developing countries. ROHDE \& Northrup (1976) estimated that, in 1975, approximately 500 million episodes of diarrhoea occurred among children in Asia, Africa and Latin America, and this resulted in between five and 18 million deaths.

Known bacterial pathogens cannot be implicated in up to $75^{\prime \prime}$ " of outbreaks of acute diarrhoeal disease (Cramblett \& Siewers, 1965). Nevertheless, until recently gastro-enteritis provided a poor hunting ground for virologists for, although such viruses as adenoviruses, echoviruses and Coxsackie viruses could be isolated from the stools of patients with acute gastro-enteritis, they could often be recovered with almost equal frequency from those without diarrhoeal disease, particularly in developing countries. However, the examination of negatively stained faecal preparations from patients with gastro-enteritis by electron microscopy has resulted in the discovery of many viruses, some of which, for example, rotaviruses and such parvovirus-like viruses as the Norwalk agent, are undoubtedly the cause of acute gastro-enteritis. The role of such other viruses as astroviruses, caliciviruses, adenoviruses and coronaviruses remains as yet to be clearly established. In general, in vitro cultivation of viruses causing gastro-enteritis in humans is either not possible or extremely difficult and of little value for routine diagnostic purposes but, since they are often excreted in very high titres, they may be detected without difficulty by electron microscopic examination of faecal extracts.

\section{Viruses known to cause gastro-enteritis}

1. Parvovinus-like viruses

Small virus particles, approximately $27 \mathrm{~nm}$ in diameter, with the morphology and biophysical characteristics of parvoviruses have been detected in bacteria-free filtrates of stools from patients with the syndrome of winter vomiting disease (endemic nausea and romiting). Family and community-wide outbreaks which occur during winter months have been described, including outbreaks in schools (KAPIKIAN et al., 1972), in which up to $50 "$ " of the staff and children were affected. Secondary attack rate of up to $30^{\prime \prime}$ " occurred among family contacts, all age-groups being affected. Nausea, vomitingsometimes projectile-and vertigo are the symptoms most commonly encountered; some patients have diarrhoea and abdominal pain. The disease has an incubation period of 24 to 36 hours and runs a short course, the duration of which is usually from 24 to 72 hours. Parvovirus-like particles may be detected in the stools by electron microscopy during the acute phase of the infection, peak excretion occurring about 36 hours after onset. An immune response may be detected by immune electronmicroscopy. The first outbreak in which the virus was characterized occurred in a primary school in Norwalk, Ohio (Kapikian et al., 1972). Since then, parvovirus-like viruses have been detected in further outbreaks in the U.S.A. (WYATT et al., 1974) as well as in the U.K. (ApPleton et al, 1977). Cross challenge studies in volunteers, together with studies by immune electron microscopy, indicate that these strains exhibit antigenic diversity (WYATT et al., 1974). Thus, although the Norwalk agent is closely related to the Montgomery County agent which was detected in a family outbreak in Maryland, U.S.A., both these viruses are unrelated to that which caused an outbreak of winter vomiting disease in Hawaii (THoRNHILL et al., 1977). W and Ditchling agents are antigenically related and caused outbreaks in schools in England (CLARKE et al., 1972; Appleton et al., 1977). However, the virus detected in faecal extracts of patients with gastro-enteritis following ingestion of cockles in 1976 (APPleton \& Pereira, 1977) appears to be unrelated to W or Ditchling agents. U.K. and U.S. strains are apparently unrelated (APPLETON \& Pereira, 1977). Antigenic comparison of strains detected in an extensive epidemic in a primary school in Australia, in which 200 of 381 children and nine of 18 teachers were involved, has not as yet been reported (CHRISTOPHER et al., 1978). Recently, a sensitive radio-immuno-assay test has been developed for detecting antibodies to Norwalk agent (GREENBERG et al., 1978). Studies on sera collected in Washington, D.C., showed that antibody is acquired gradually with age, about $50 \%$ of adults having immunity. The role of parvovirus-like viruses in acute gastro-enteritis in developing countries remains to be determined but preliminary studies conducted on sera collected in Guatemala and rural Bangladesh suggest that the incidence of infection does not differ markedly from that in developed countries, since the pattern of acquisition of antibody is similar (GREENBERG \& KaPIKIAN, 1978).

\section{Rotaviruses}

Rotaviruses form a distinct genus in the family of reoviridae. Virus particles contain double-stranded RNA and are approximately 65 to $70 \mathrm{~nm}$ in diameter and have a characteristic double capsid. Radiating 
spoke-like capsomeres are a characteristic feature of the inner capsid, this being surrounded by the outer capsid which provides the particle with a sharply defined circular outline (Fig. 1). These viruses have been provisionally designated "rotaviruses" because of the similarity of the intact particle to the appearance of a wheel (rota = Latin for wheel) (FLEWETT et al., 1974). Rotaviruses have been detected, not only in children but in the young of many animal species, including mice, calves, piglets, monkeys, lambs, voles, foals, antelopes and rabbits; virus-specific antibodies have been detected in brown bears, guinea-pigs and dogs (DERBYSHIRE \& WOODE, 1978). It seems probable that the young of all mammalian species may have their own rotaviruses. Group-specific antigens associated with the inner capsid layer are probably common to rotaviruses of all animal species; antigens associated with the outer capsid are species-specific (WoOdE et al., 1976).

Rotaviruses were first detected in children by electron-microscopy in ultra-thin sections of the duodenal mucosa of six of nine babies during the acute phase of gastro-enteritis but viruses were not detected in babies who did not have diarrhoeal disease (BIsHop et al., 1973). Within a short period, similar virus particles were detected by negative staining techniques in faecal extracts of children with acute gastro-enteritis in many parts of the world, including the tropics (LANCET, 1975). The accumulated data from studies in temperate climates showed that infection occurred most frequently in children between six and 24 months

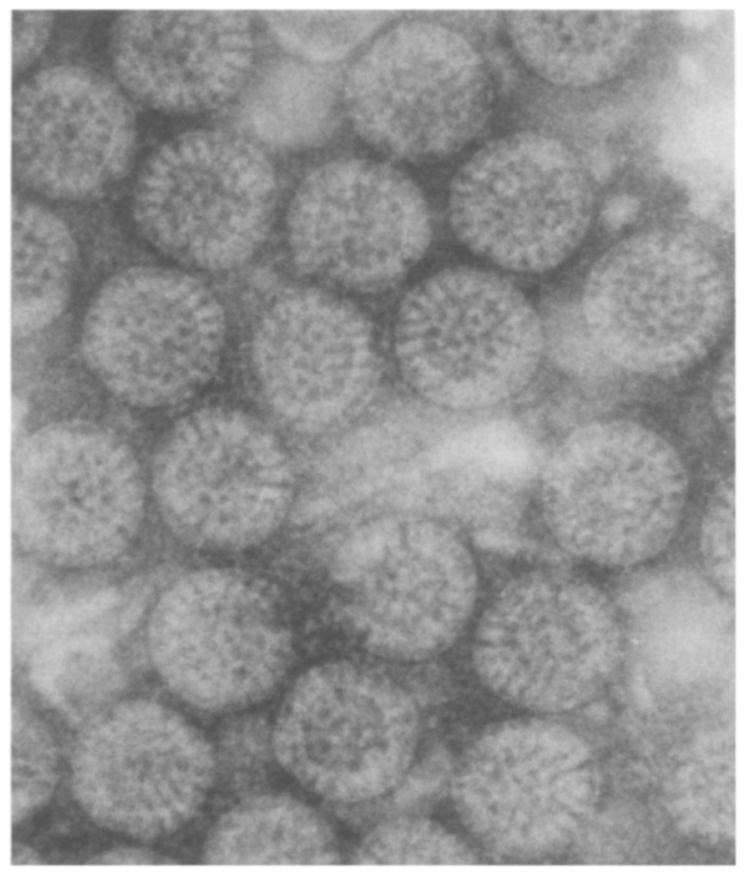

Fig. 1. Electronmicrograph of rotaviruses present in faecal extracts of a child with acute gastro-enteritis $(\times 200,000)$. of age (by school age most children have antibody) (ElIAS, 1977) and that infection occurred most commenly during winter months. Thus, during the course of any one year, rotaviruses may be detected in the stools of up to 40 to $50 \%$ of children with acute gastro-enteritis but rarely among controls; during winter months the incidence might rise as high as 75 to $80 \%$ (DAvidson et al., 1975). The incubation period is usually of the order of one to three days and rotaviruses are generally excreted in very large quantities (up to $10^{10}$ particles per gram of faeces), virus excretion usually persisting for about a week, being maximum from three to four days after the onset of symptoms. A study among children admitted to hospital in Toronto showed that, in approximately a third of cases, rotavirus infection, often severe, was the result of hospital-acquired infection (MIDDLETON et al., 1977). Rotavirus infection may also be endemic in newborn nurseries but, in contrast with findings in older children, the newborn generally experiences mild or asymptomatic infection (CHRYsTIE et al., 1978). The reason for this is unknown. Rotavirus has been reported less frequently among adults. However, approximately 25 to $35 \%$ of adult family contacts of children with rotavirus diarrhoea may show a rise in rotavirus antibody titre and some have mild diarrhoea (KAPIKIAN et al., 1976; Tufvesson et al., 1977). However, despite the fact that most adults have antibodies to rotavirus, rotaviruses have been detected in the stools of adults with moderately severe gastro-enteritis who had not had a known close contact with children (VON BONSDORFF et al., 1976). Furthermore, outbreaks of rotavirus infection have even been reported in homes for old people.

In developing countries, such factors as malnutrition and debilitating diseases may influence the outcome of any acute diarrhoeal episode. However, there have been comparatively few studies conducted in the tropics in which specimens have been collected over a sufficiently extended period to show whether rotavirus infection is caused by climatic factors. Those that have show no consistent pattern (Table). Thus, studies in southern India (Vellore) and central Australia (Alice Springs) suggest that rotavirus infection occurs most commonly during the cooler months. However, in parts of those countries with high ambient temperatures throughout the year (Calicut and Darwin), there was an increased prevalence of rotavirus infection during or just after the rainy season (MATHAN et al., 1977; ShNAGL et al., 1977; Walker \& Marshall, 1978, personal communication). However, in Central America (Guatemala and Costa Rica), there was no apparent association between ambient temperature and rotavirus infection (WYATT et al., 1978), although studies in Costa Rica suggested that rotavirus infection tended to occur during periods of low relative humidity (MATA, 1978). Rotavirus could only be detected in $14^{\circ}$ \% of episodes of acute diarrhoeal disease in Guatemala. However, infections were generally more severe than those caused by other agents, since they caused vomiting and dehydration significantly more frequently (WYATT et al., 1978). In Bangladesh, rotaviruses were associated with 
$40 \%$ of episodes of acute diarrhoeal disease and, as in temperate climates, infection occurred most commonly in children between six and 24 months of age (Yolken, 1978, personal communication). It is encouraging that studies carried out in southern India suggest that oral rehydration may be used effectively in the treatment of infants with rotavirusinduced diarrhoea (MATHAN et al., 1977; Mathan, 1978, personal communication).

Currently, evidence is accumulating that there are multiple serotypes of human rotaviruses (Flewet et al., 1978; Fonteyne et al., 1978; ZISSIS \& LAMBERT, 1978) and studies on children who have been reinfected have shown that this usually results from infection by different serotypes. Large-scale prospective studies to assess the role of rotaviruses as a cause of severe gastro-enteritis in developing countries were, until recently, hindered by the fact that such sophisticated techniques as electron microscopy were required for diagnosis. However, the ELISA test is of comparable sensitivity to electron microscopy and can be readily carried out in developing countries with little cost, provided standardized reagents are available (YoLKen et al., 1977). The ELISA test may be used, not only to detect rotaviruses and compare their antigenicity, but also to detect immune responses to them. It is hoped that much invaluable epidemiological data relating to the role of rotavirus infection in different communities in developing countries may result from the widescale use of this technique.

\section{Other viruses}

The role of such other viruses as astroviruses, caliciviruses, coronaviruses and even adenoviruses as a cause of acute diarrhoeal disease in infancy and childhood must for the present remain more speculative, for these viruses may often be detected among asymptomatic controls. Other viruses may also be present in faecal extracts at the same time, and virus excretion may not always be associated with the development of immune responses.

Astroviruses are approximately 25 to $28 \mathrm{~nm}$ in diameter, have an entire outer edge and a starshaped surface configuration which may be five- or six-pointed (MADELEY \& COSGROVE, 1975) (Fig. 2). Evidence is beginning to accumulate to suggest that these viruses may well be human pathogens in young babies. Thus, studies in Glasgow have shown that about $80 \%$ of babies excreting virus have gastro-intestinal symptoms and that, when viruses are also present in faecal extracts, astroviruses are usually the first to appear (Madeley, 1978, personal communication). An outbreak of astrovirus-associated diarrhoea in a children's ward affecting both children and staff has recently been described, and some of those affected were shown to develop an immune response (KURTZ et al., 1977). Astroviruses have also been shown to cause mild gastro-intestinal symptoms when fed to adult volunteers (REED et al., 1978).

Caliciviruses are of approximately $30 \mathrm{~nm}$ diameter and appear to have characteristic stainfilled, cup-like depressions on the surface of the particle (MADELEY \& CoSGrove, 1976) (Fig. 3). Their association with acute gastro-enteritis is 


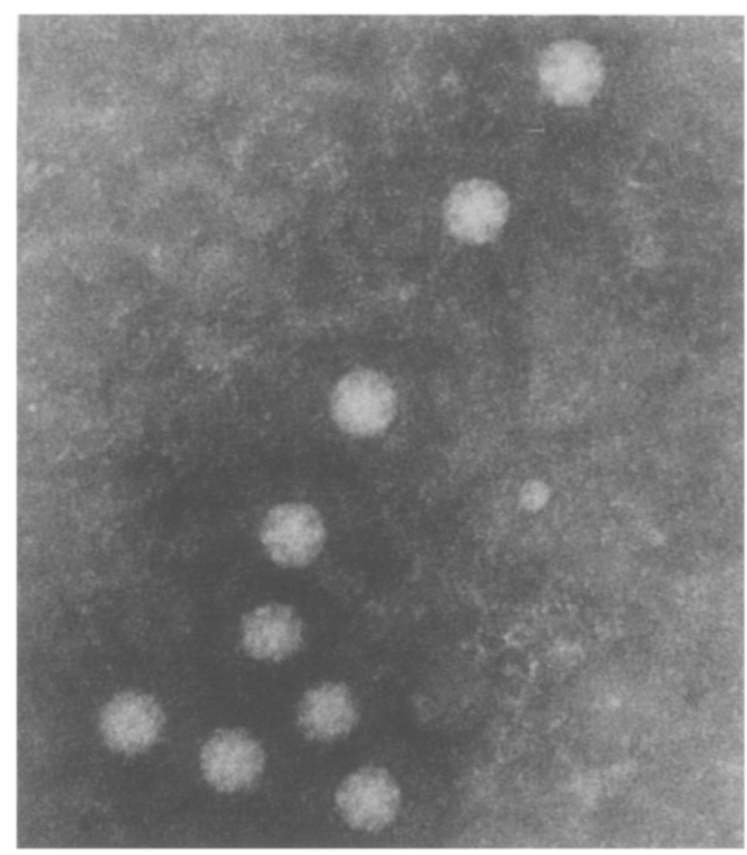

Fig. 2. Electronmicrograph of astroviruses $(\propto 200,000)$.

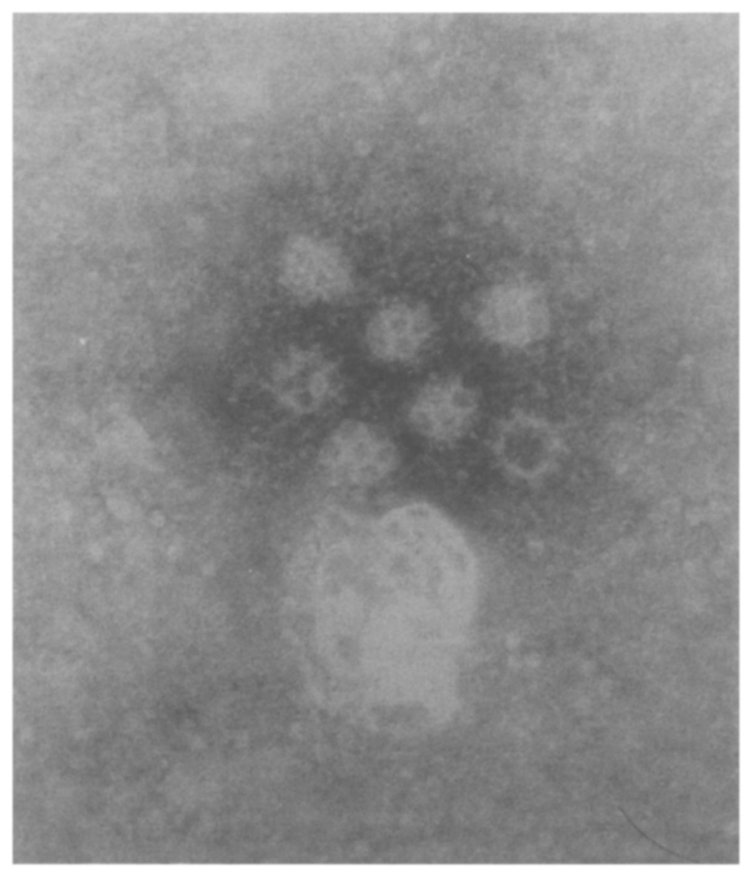

Fig. 3. Electronmicrograph of caliciviruses $(\because 200,000)$.

rather more tenuous than that of astroviruses as yct, although there has been a recent report of caliciviruslike virus particles being detected in the stools of children and staff in an outbreak of winter vomiting disease in a primary school (MCSWIGGAN et al., 1978).

Since coronaviruses are important causes of severe diarrhoeal disease in pigs (transmissible gastro-enteritis) and calves (TAJIMA, 1970; STAIR et al., 1972), many workers have hoped to identify their counterpart in man. However, unlike rotaviruses, evidence that coronaviruses cause human gastro-intestinal infection is currently somewhat tenuous. Corona-like virus particles have been detected in patients with both acute and chronic diarrhoeal disease, as well as in asymptomatic persons. Although some workers have expressed doubt as to whether the corona-like virus particles detected were indeed viruses rather than bacterial substructures or fragments of gut epithelium, it is encouraging that coronavirus-like particles have now been propagated in both cell and organ cultures (CAul \& Egglestone, 1977). Fringed, pleomorphic particles, resembling "coronaviruses, have been detceted in $90 \%$, of faccal cxtracts obtained in parts of southern India where tropical sprue is endemic. These particles were present in all age groups except for newborn infants, but they were detected with almost equal frequency among patients and asymptomatic persons (MATHAN $e t$ al., 1975; Mathan \& Mathan, 1978). The role of these virus-like structures in tropical sprue is therefore far from clear. However, it is important that further studies, in which attempts are made to cultivate these virus-like particles, be carried out.

Although adenoviruses may be present in the stools of children with and without diarrhoeal disease, explosive outbreaks in hospital of acute gastro-enteritis in infancy and childhood may sometimes be caused by adenoviruses (FLEWETT et al., 1975) and, on occasion, infection may be fatal (WhITELAW et al., 1977). It is of interest that, despite the presence of very large quantities of virus, enteric adenoviruses can rarely be propagated in cell culture (MADELEY et al., 1977).

\section{Acknowledgement}

I am grateful to Mr. I. L. Chrystie for the electron-micrographs.

\section{References}

Appleton, H., Buckley, M., Thom, B. T., Cotton, J. L. \& Henderson, S. (1977). Virus-like particles in winter vomiting disease. Lancet, i, 409-411.

Appleton, H. \& Pereira, M. S. (1977). A possible virus aetiology in outbreaks of food poisoning from cockles. Lancet, i, 780-781.

Bishop, R. F., Davidson, G. P., Holmes, I. H. \& Ruck, B. J. (1973). Virus particles in epithelial cells of duodenal mucosa from children with non-bacterial gastroenteritis. Lancet, ii, 12811283.

Caul, E. D. \& Egglestone, S. I. (1977). Further studies on human enteric corona-viruses. Archives of Virology, 54, 107-117.

Christopher, P. J., Grohmann, G. S., Millsom, R. H. \& Murphy, A. M. (1978). Parvovirus gastroenteritis $\rightarrow$ a new entity for Australia. Medical fournal of Australia, i, 121-124. 
Chrystie, I. L., Totterdell, B. \& Banatvala, J. E. (1978). Asymptomatic endemic rotavirus infections in the newborn. Lancet, $\mathbf{i}, 1176-1178$.

Clarke, S. K. R., Cook, A. T., Egglestone, S. I., Hall, T. S., Miller, D. I., Reed, S. E., Rubenstein, D., Smith, A. J. \& Turrell, D. A. J. (1972). A virus from epidemic vomiting disease. British Medical fournal, iii, 86-89.

Cramblett, H. G. \& Siewers, C. M. G. (1965). The etiology of gastroenteritis in infants and children, with emphasis on the occurrence of simultaneous mixed viral-bacterial infections. Pediatrics, 35, 885-898.

Davidson, G. P., Bishop, R. F., Townley, R. R. W., Holmes, I. H. \& Ruck, B. J. (1975). Importance of a new virus in acute sporadic enteritis in children. Lancet, i, 242-246.

Derbyshire, J. B. \& Woode, G. N. (1978). Classification of rotaviruses: Report from the World Health Organization/Food and Agriculture Organization Comparative Virology Program.

Elias, M. M. (1977). Distribution and titres of rotavirus antibodies in different age groups. Fournal of Hygiene, 79, 373.

Flcwett, T. H., Bryden, A. S., Davies, H. \& Morris, C. A. (1975). Epidemic viral enteritis in a longstay children's ward. Lancet, $i, 4-5$.

Flewett, T. H., Bryden, A. S., Davies, H., Woode, G. N., Bridger, J. C. \& Derrick. J. M. (1974). Relation between viruses from acute gastroenteritis of children and newborn calves. Lancet, ii, 61-63.

Flewett, T. H., Thouless, M. E., Pilfold, J. N., Bryden, A. S. \& Candeias, J. A. N. (1978). More serotypes of human rotavirus. Lancet, ii, 632.

Fonteyne, J., Zissis, G. \& Lambert, J. P. (1978). Recurrent rotavirus gastroenteritis. Lancet, i, 983.

Greenberg, H. B. \& Kapikian, A. Z. (1978). Detection of Norwalk agent antibody and antigen by solid phase radioimmunoassay and immuneadherence haemagglutination assay. Fournal of the American Veterinary Association, 173, 621-623.

Greenberg, H. B., Wyatt, R. G., Valdesuso, J., Kalica, A. R., London, W. T., Chanock, R. M. \& Kapikian, A. Z. (1978). Solid phase microtitre radioimmunoassay for detection of acute nonbacterial, epidemic gastroenteritis virus and its antibodies. Fournal of Medical Virology, 2, 97-108.

Kapikian, A. Z., Kim, H. W., Wyatt, R. G., Cline, W. L., Arrobio, J. O., Brandt, C. D., Rodriguez, W. J., Sack, D. A., Chanock, R. M. \& Parrott, R. H. (1976). Human reovirus-like agent as the major pathogen associated with "winter" gastroenteritis in hospitalized infants and young children. New England fournal of Medicine, 294, 965-972.

Kapikian, A. Z., Wyatt, R. G., Dolin, R., Thornhill, T. S., Kalica, A. R. \& Chanock, R. M. (1972). Visualization by immune electron microscopy of a $27-\mathrm{nm}$ particle associated with acute infectious non-bacterial gastroenteritis. Fournal of Virology, 10, 1075-1081.

Kurtz, J. B., Lee, T. W. \& Pickering, D. (1977). Astrovirus associated gastroenteritis in a children's ward. Fournal of Clinical Pathology, 30, 948-952.
Lancet (1975). Rotaviruses of man and animals. Lancet, i, 257-259.

McSwiggan, D. A., Cubitt, D. \& Moore, W. (1978). Calicivirus associated with Winter Vomiting Disease. Lancet, i, 1215.

Madeley, C. R. \& Cosgrove, B. P. (1975). $28 \mathrm{~nm}$ particles in faeces in infantile gastroenteritis. Lancet, ii, 451-452.

Madeley, C. R. \& Cosgrove, B. P. (1976). Caliciviruses in man. Lancet, i, 199-200.

Madeley, C. R., Cosgrove, B. P., Bell, E. J. \& Fallon, R. J. (1977). Stool viruses in babies in Glasgow. 1. Hospital admissions with diarrhoea. Journal of Hygiene, 78, 261-273.

Mata, L. (1978). Rotavirus diarrhoea in Costa Rica. In: Abstracts of the Fourth International Congress for Virology, The Hague, 30th August-6th September, 1978. Wageningen: Centre for Agricultural Publishing and Documentation, p. 469.

Mathan, M., Jayaram Panicker, C. K. \& Mathan, V. I. (1977). Acute diarrhoea in infants in India. Some aetological and epidemiological aspects. Presented at the XVth International Congress of Pediatrics, New Delhi, October 1977.

Mathan, M. \& Mathan, V. I. (1978). Coronaviruses and tropical sprue in Southern India. In: Abstracts of the Fourth International Congress for Virology, The Hague, 30th August-6th September, 1978. Wageningen: Centre for Agricultural Publishing and Documentation, p. 469.

Mathan, M., Mathan, V. I., Swaminathan, S. P., Yesudoss, S. \& Baker, S. J. (1975). Pleomorphic virus-like particles in human faeces. Lancet, $\mathbf{i}$, 1068-1069.

Middleton, P. J., Swymanski, M. T. \& Petrie, M. (1977). Viruses associated with acute gastroenteritis in young children. American fournal of Diseases of Children, 131, 733-737.

Reed, S. E., Kurtz, J. B. \& Lee, T. W. (1978). Inoculation of volunteers with a human astrovirus. In: Abstracts of the Fourth International Congress for Virology, The Hague, 30th August6th September, 1978. Wageningen: Centre for Agricultural Publishing and Documentation, p. 461 .

Rohde, J. E. \& Northrup, R. S. (1976). Taking science where diarrhoea is. Acute diarrhoea in childhood. In: Ciba Foundation Symposium 42. Amsterdam: Elsevier, Excerpta Medica, North Holland, pp. 339-366.

Shnagl, R. D., Holmes, I. H., Moore, B., Lee, P., Dickinson-Jones, F. \& Gust, I. D. (1977). An extensive rotavirus outbreak in aboriginal infants in central Australia. Medical fournal of Australia, i, $259-260$.

Stair, E. L., Rhodes, M. B., White, R. G. \& Mebus; C. A. (1972). Neonatal calf diarrhoea: purification and electron-microscopy of a coronavirus-like agent. American fournal of Veterinary Research, 33, $1147-1156$.

Tajima, N. (1970). Morphology of transmissible gastroenteritis virus of pigs. A possible member of coronaviruses. Archives of Virology, 29, 105108.

Thornhill, T. S., Wyatt, R. G., Kalica, A. R., Dolin, R., Chanock, R. M. \& Kapikian, A. Z. 
(1977). Detection by immune electron microscopy of 26- to 27-nm viruslike particles associated with two family outbreaks of gastroenteritis. Fournal of Infectious Diseases, 135, 20-27.

Tufvesson, B., Johnsson, T. \& Persson, B. (1977). Family infections by reo-like virus. Comparison of antibody titres by complement fixation and immuno-electro-osmophoresis. Scandinavian fournal of Infectious Diseases, 9, 257-261.

Von Bonsdorff, C.-H., Hovi, T., Makela, P., Hovi, L. \& Tevalvoto-Aarnio, M. (1976). Rotavirus associatcd with acute gastroenteritis in adults. Lancet, ii, 423.

Whitelaw, A., Davies, H. \& Parry, J. (1977). Electron microscopy of fatal adenovirus gastroenteritis. Lancet, i, 361 .

Woode, G. N., Bridger, J. C., Jones, J. M., Flewett, T. H., Bryden, A. S., Davies, H. A. \& White, G. B. B. (1976). Morphological and antigenic relationships between viruses (rotaviruses) from acute gastroenteritis of children, calves, piglets,

\section{Admission to the Fellowship of the Society}

All registered medical and veterinary practitioners and others interested in scientific pursuits relating to tropical medicine, whose qualifications are deemed satisfactory by the Council, are eligible for election as Fellows of the Society.

The annual subscription payable by Fellows is $£ 15.00$ which becomes due in advance on the 1st April of each year.

The Transactions and the current Year Book of the Society are posted regularly to every Fellow whose subscription is not in arrear.

Further information may be obtained from the Hon. Secretaries, Manson House, 26 Portland Place, London WIN 4EY, or from the Local Secretary of the district. mice and foals. Infection and Immunity, 14, 804-810.

Wyatt, R. G., Dolin, R., Blacklow, N. R., DuPont, H. L., Buscho, R. F., Thornhill, T. S., Kapikian, A. Z. \& Chanock, R. M. (1974). Comparison of three agents of acute infectious nonbacterial gastroenteritis by cross-challenge in volunteers. Fournal of Infectious Diseases, 129, 709-714.

Wyatt, R. G., Yolken, R. H., Urrutia, J. J., Mata, L., Greenberg, H. B., Chanock, R. M. \& Kapikian A. Z. (1978). Diarrhoea associated with rotavirus in rural Guatemala: a longitudinal study of 24 infants and young children.(in press.)

Yolken, R. H., Kim, H. W., Clem, T., Wyatt, R. G., Kalica, A. R., Chanock, R. M. \& Kapikian, A. Z. (1977). Enzyme-linked immunosorbent assay (ELISA) for detection of human reovirus-like agent of infantile gastroenteritis. Lancet, ii, 263-267.

Zissis, G. \& Lambert, J. P. (1978). Different serotypes of human rotaviruses. Lancet, i, 38.

\section{CORPORATE MEMBERSHIP WITH THE ROYAL COMMONWEALTH SOCIETY, 18 NORTHUMBERLAND AVENUE, LONDON, WC2 5BJ}

The Society has taken up Corporate Membership with the above Society, which has premises just off Trafalgar Square. Overseas Fellows can now use the facilities of this Society, when they come to London, for a period of 21 days in any three months provided that all booking is done through the Secretary at Manson House. Fellows who wish to use these facilities must give the Secretary adequate notice of their requirements particularly during the summer when, at least two months' notice will be required. Details of the facilities available will be sent to Fellows on request.

\section{CHRISTMAS CARDS}

The Society's Christmas card measures 145 . $100 \mathrm{~mm}$ and consists of a wood-cut depicting the front elevation of Manson House with the words "With best wishes for a happy Christmas" inside-all printed in black and white.

Price, complete with envelope, $£ 1 \cdot 00$ per $10, £ 8 \cdot 00$ per 100 , post free.

Orders to: The Secretary, Royal Society of Tropical Medicine and Hygiene, Manson House, 26 Portland Place, London W1N 4EY. 